Original Paper

http://indexmedicus.afro.who.int

\title{
Cannabis cultivation and deforestation in the Site of Bio Ecological Interest (SIBE) of Bouhachem, Morocco
}

\author{
Hilaire Chokona GATCHUI ${ }^{1,2^{*}}$, Georges SMEKTALA ${ }^{3}$, David SOLANO ${ }^{4}$, \\ Lahcen TAIQUI ${ }^{5}$ and Arlende F. NGOMENI ${ }^{6}$
}

\author{
${ }^{I}$ West Regional Delegation of the Ministry of Environment, Nature Protection and Sustainable Development \\ (MINEPDED), Cameroon. PO Box 977 Bafoussam, Cameroon. \\ ${ }^{2}$ Centre for the Promotion of Sustainable Development (CPSD), Yaoundé, Cameroon. \\ ${ }^{3}$ AgroParisTech-ENGREF, 648, Rue Jean-Fançois Breton, 34086 Montpellier Cedex 4 France. \\ ${ }^{4}$ Department of Biology, University Abdelmalek Essaâdi of Tetouan, Morocco. \\ ${ }^{5}$ Forest Sciences Centre of Catalonia (CTFC), Crta. de Sant Llorenç de Morunys, Km.2, 25280 Solsona, Spain. \\ ${ }^{6}$ Institute of Agricultural Research for Development, Dschang, Cameroon. \\ *Corresponding author; E-mail: hilairechokona@yahoo.fr, Tel: +237 77601748
}

\begin{abstract}
Located in the North of Morocco, Bouhachem forest (about 8000 ha) is threatened by increased deforestation. In order to assure the sustainable management of this forest, the study of its landscape dynamic has been conducted, with emphasis on the role of cannabis cultivation and deforestation. For this, forest inventory was done, satellite images covering 26 years period were analysed, interviews of stakeholders conducted and the archives on the management of the forest checked. The forest basal area is $34.6 \mathrm{~m}^{2} / \mathrm{ha}$ in average. Canopy closure, stand density, rock exposition, and stump density average values were respectively $43 \%, 1001 \mathrm{stem} / \mathrm{ha}, 24 \% 187 \mathrm{stump} / \mathrm{ha}$, for a wild stump rate of $18.7 \%$. The total forest cover has shrunk by $11 \%$ between 1984 and 2010.The main reasons of forest depletion are: demographic explosion, erosion land slide, illegal logging and cannabis cultivation around which are gravitating an increased demand of forest resources, livestock grazing, corruption, poor surveillance, forest fire.
\end{abstract}

(C) 2014 International Formulae Group. All rights reserved.

Keywords: Bouhachem forest, livestock grazing, corruption, remote sensing and GIS, model of deforestation.

\section{INTRODUCTION}

In 2010 , the total forest area of the world was estimated to be just over 4 billion hectares. From these forest lands, 5,131,000 ha belong to Morocco, covering $11 \%$ of the country (FAO, 2010). According to this same source, the rate of deforestation that was at about $-3000 \mathrm{ha} / \mathrm{yr}$ showing a lost of forest, has changed positively to about 10000 ha ha/yr between 2005 - 2010 meaning an increase in forest area. But unfortunately, this data hide a large disparity of situations that characterised specific area of the country. In Bouhachem forest, the diagnosis of forest sector shows an upsetting deforestation and conflicting relationship between the administration and forest users. According to Taiqui et al. (2008), the occidental and central Riff climate is 
favourable to natural development of Mediterranean forest. But the risks of deforestation are present because of poor resources and economics infrastructures, and the great human density estimated at 213 habt $/ \mathrm{km}^{2}$ in the region of Tanger-Tetouan according to the census of 2004 (Haut Commissariat au Plan, 2005). As stated by the United Nations Office on Drugs and Crime (2003), a quarter of the agricultural land in the Rif region was occupied by an expanding cannabis cultivation (known as kiff in the area) leading to the deforestation and soil erosion of this fragile ecosystem. This unfortunate situation takes a particular dimension linked to uncontrolled cultural changes generated by unlawful character of this product and its high economic value (Taiqui et al., 2008).

According to Regato and Salman (2008) the Convention on Biological Diversity Conference of Parties has adopted a programme of work on mountain biodiversity with the overall goal of significantly reversing mountain biodiversity loss by 2010. The conservation and sustainable development in mountain chains became a high priority in 2002, when the international community significantly raised awareness on the importance of mountains to life and the need to improve mountain environments and the livelihoods of mountain people. As part of the mountainous area of Morocco, the Bouhachem forest (Figure 1) constitutes a rich natural patrimony (Chambouleyron, 2012). It has been identified as a Site of Bio-Ecological Interest (SIBE) of priority 1 in 1995 , by the Morocco's Ministry in charge of forest. However, this wealth is unfortunately threatened by increased deforestation (CTFC, 2010).

A survey conducted by the United Nations Office on Drugs and Crime (2003) on cannabis cultivation in the area of Rif showed a decrease by $40 \%$ of cultivated surfaces at early 2000, passing from 120,500 ha to 72,500 ha. Despite the fact that the highest reduction was observed in the province of Chefchaouen, this province still remained the biggest grower of kiff for the production of haschisch. One can therefore understand why Kamel (2009) said that "Riff rhymes with Kiff". The Bouhachem forest reserve is one of the few patches of forest which are left in the Mediterranean and therefore concerns about changes in the size and quality of these ecosystems have been growing more and more since these sensitive forests lands are being converted into other land uses (Ngufor, 2010).

\section{MATERIALS AND METHODS \\ Study area}

The area of interest is the forest of Bouhachem, located at the north of Morocco, in the triangle formed by the provinces of Tetouan, Chefchaouen, and Larache (Figure 1). This SIBE extends on a surface area of approximately 8000 ha (CTFC, 2010). As a forest with multiple interests, it is one of the core areas of the Intercontinental Biosphere Reserve of the Mediterranean MoroccoAndalusia/Spain (International Birds of the Strait Fair, 2010), Vocation zone $\mathrm{N}^{\circ} 1$ of the Natural Regional Park of Bouhachem and a SIBE (Service des Eaux et Forêts du Maroc, 2004).

\section{Data collection and processing \\ Satellite images}

Three satellite images of vegetative season of different years (Landsat TM of August 1984, Landsat ETM+ of August 1999, and SPOT image of June 2010) were used for image classification. From these satellite imageries, the study area (8175 ha) was subset, in order to obtain only our Area Of Interest (AOI). A GPS permitted to take ground control points and for the location of inventory plots. 
To process the images, remote sensing and GIS software were used. The basic methodology was simply a comparison of three satellite images of the study area. These images were then overlaid in a change detection process to show geographically the specific changes in land cover ( $\mathrm{Lu}$ et al., 2004). The supervised classification was performed on the raw images of Landsat and a $10 \mathrm{~m}$ SPOT degraded into $30 \mathrm{~m}$ resolution and the accuracy assessment was done during and after classification (Chokona, 2006), (Chokona, 2011). A post classification accuracy assessment was done using 350 independent points derived randomly. For the three images (1984, 1999 and 2010), this was respectively $88.29 \%, 86 \%$ and $82.86 \%$.

\section{Choice of Land Use Land Cover classes}

In the framework of this study, and according to our objectives, 5 classes were discriminated: Matorral (SHRUB), which included the shrub lands; cultivated lands, grass lands and bare lands were grouped together in one class called Cultivated/Bare/Grass Land (CBGL) because of their similarity in the period of the year (June-August); Forest was divided according to canopy closure. In this wise, we identified the class Closed Forest (CF) separately from Open or Light Forest class (OLF) Exposed Rock (ER) due to their importance in the area. To this class, we added settlements and tarred road identified on the image of 2010.

\section{Archive searching}

In order to collect data on some infractions on the forest such as forest fire, illegal logging, forest clear off and forest land plough and to have information about livestock and farming, a careful check of archives in the Service of Infraction and Material of the Centre of Forest Development at the Provincial Office for Forest and at the Provincial Office of Agriculture in
Chefchaouen was necessary. These data were analysed through descriptive statistic method.

\section{Forest inventory}

Circular sample plots of radius varying so that it can contain 15 to 25 trees with not less than $7.5 \mathrm{~cm}$ of diameter and a height greater than $1.3 \mathrm{~m}$ were established. Plot radius was reduced or increased according to the density of the plot, but with a maximum of $30 \mathrm{~m}$ and a minimum of $5 \mathrm{~m}$. The sample plots were systematically distributed in the forest, their centre being separated by $250 \mathrm{~m}$ in transect with the difference that in area with less than $30 \%$ of tree coverage, this distance was twice greater. The distance between transects was also set at $250 \mathrm{~m}$. A total of 501 were inventoried. These sample plots were also used as ground control points for land cover discrimination, image interpretation and classification. Inventory sheets allowed collecting data on the following variable of the study area: Slope (Degree); Altitude (Meter); Rock cover (Percentage); tree Density (number of trees per ha); basal area (square meters per ha); Diameter of trees (Centimetres); Canopy closure (Percentage); Erosion (Presence or Absence); Pasture sign (Presence or Absence); Stump density (Number per ha). These data were analysed through statistic descriptive method. To have an idea of human activities and specially livestock grazing on the destruction of the forest, the Wild Stump Rate (SR) defined as the relative abundance of wild stump compare to that of trees were calculated. Wild Stump Rate $(\mathrm{SR})=$ Wild Stumps Density (d) divided by tree density (D): (SR=d*100/D).

\section{Survey on the traditional use of forest}

The understanding of the main elements of local forest management (area with different use interest and problematic, collective management rules, land ownership process, area of conflict identification) was 
not possible without a survey of the population combined with field observation. For this survey, the grounded theory method was used (Weber and Beaud, 2003). Otherwise, the survey guide was improved during the phase of discussion and while meeting the key persons of the area. The idea was not to deeper the sociological aspect of forest management, but instead to follow a method that put the surveyed person in confidence. It was therefore interesting to have been documented on what is happening on the targeted field (Leguet, 2008). The data collected from field observation combined with those of the survey of the population, generated the data on the impact of population on the forest. These data also served to designing the model of deforestation of Bouhachem forest using system dynamic modelling software (STELLA).

\section{RESULTS}

\section{The SIBE of Bouhachem: present state}

Bouhachem forest is characterised by a canopy closure average of $43 \%$, a tree density of 1001 trees/ha in average. Almost all the highest top of the mountains are covered by rock, leading to an average rock exposition of $24 \%$. The average basal area and stump density are respectively $34.6 \mathrm{~m}^{2} /$ ha and 187 stump/ha. The "Stump Rate (SR)" is estimated to be $187 * 100 / 1001=18.7$, meaning that in Bouhachem forest, beside each 100 trees about 19 stumps will be counted. The J inversed diameter class distribution (Figure 2) shows that Bouhachem forest is still a natural forest.

\section{LU/LC Classification and Change Dynamics of the SIBE of Bouhachem}

The initial landscape organization in 1984 was strongly dominated by forest cover, especially Closed Forest. This was still the case in 1999 and 2010 (Figure 3). The classification results reveal that this dominant land cover class represented 4176 ha $(51.1 \%)$ of the area in 1984, 4207 ha $(51.5 \%)$ in 1999 , and $3299(40.4 \%)$ in 2010. This domination was followed by Open/Light Forest and Matorral. Cultivated/Bare/Grass Land and Exposed Rock were the less represented (). From this table, and according toFigure 4 (a), the dynamic shows that:

- For the first period (1984-1999), Closed Forest increased by 31 ha due to pine plantation, while the Open/Light Forest decreased by 470 ha. In this same time, Matorral increased by 296 ha, and Cultivated/Bared/Grass Land and Exposed Rock by 65 and 78 ha respectively. In order to have an idea of the changes in the overall forest area (Closed Forest and Open/Light Forest), it can be observed that difference of the sum of these two classes has reduced by 439 ha, meaning a lost in forest cover within this period.

- During the second period, 1999-2010, the size of Closed Forest decreased by 908 ha in contrary to the first period while Open/Light forest witnessed an increase of 619 ha. Shrub and Exposed Rock gained 117 ha and 230 ha respectively, but Cultivated/Bared/Grass Land in opposition to expectation lost 57 ha. Concerning the forest coverage in general, the trend has been the same like in the first period with a depletion of 289 ha in size.

To summarise the changes during the 26 years, the results of classifications (Figure 4 b) show an increase in the class of Cultivated/Bared/Grass Land. The area of Exposed Rock almost doubled, while Matorral or Shrub Land and Open/Light Forest also increased. Unfortunately for the Closed Forest, the area drastically reduced by 877 ha and in general, forest cover has shrunk by 729 ha. 


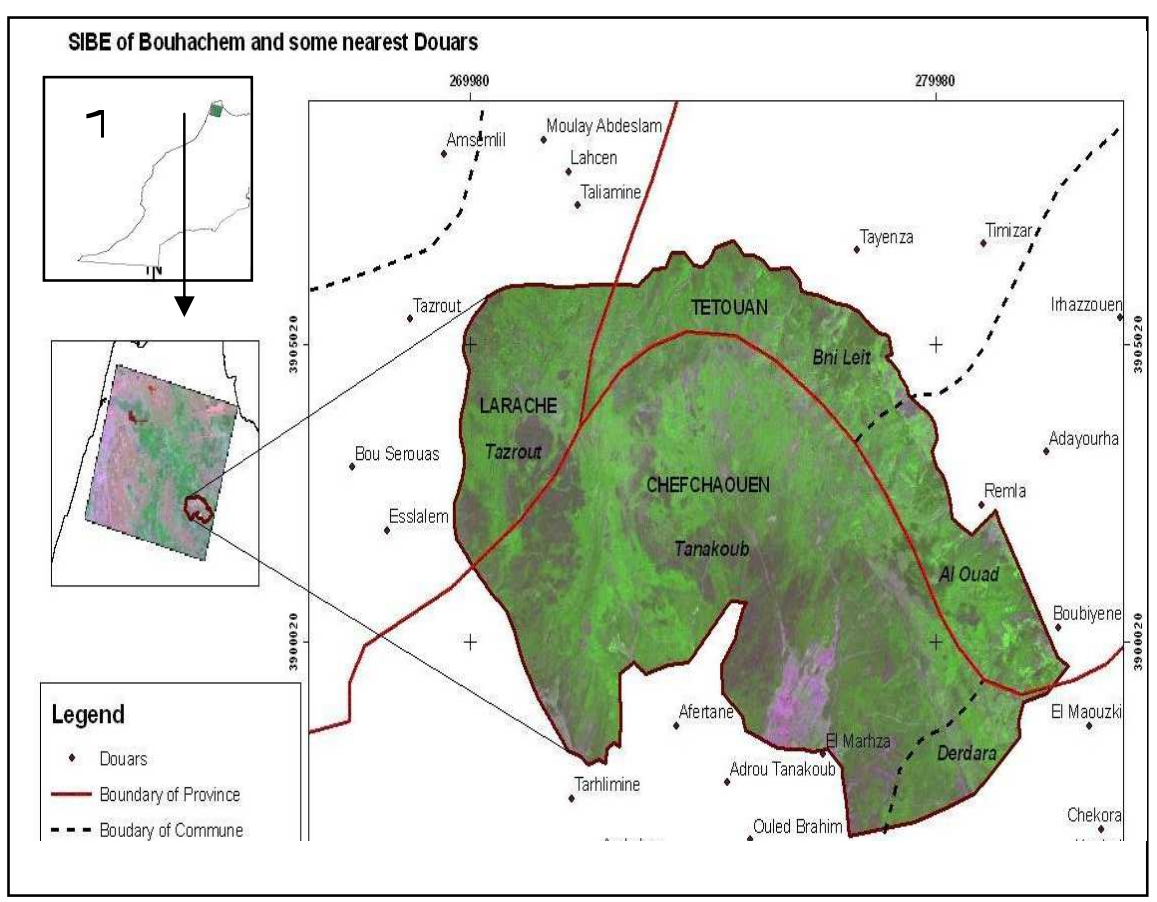

Figure 1: Localisation of the study area in Morocco.

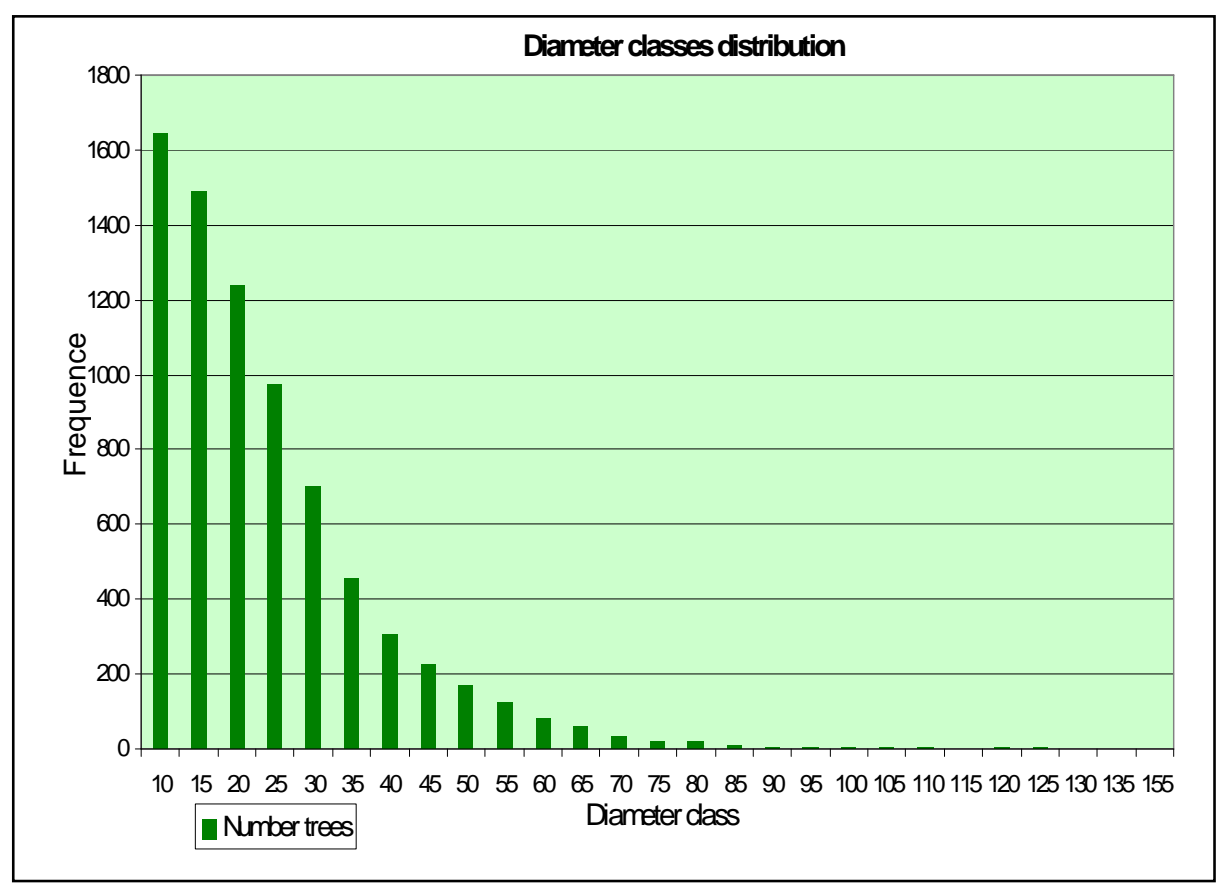

Figure 2: Diameter distribution of the SIBE of Bouhachem. 


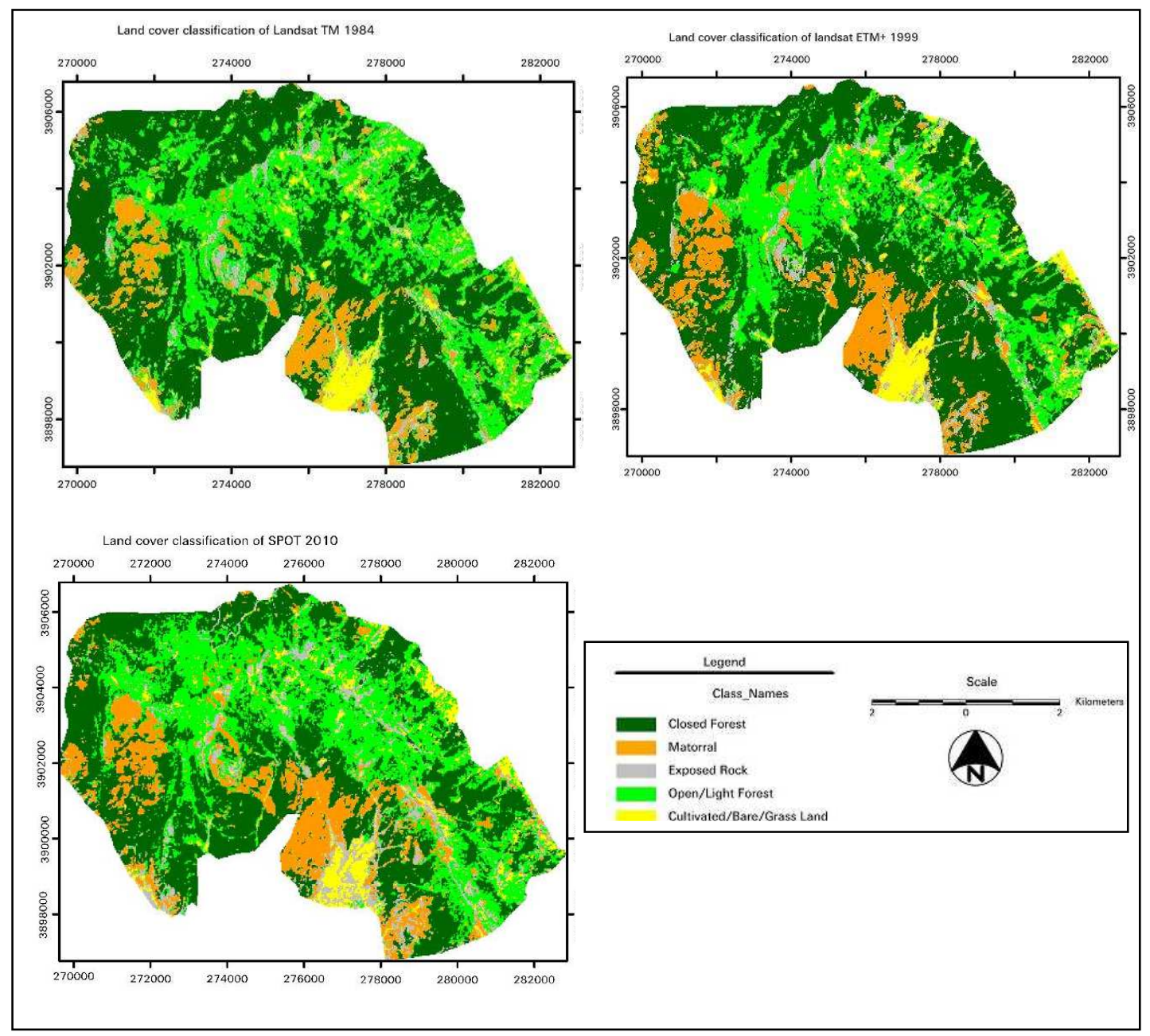

Figure 3 : Classification of satellite images of 1984, 1999, 2010 of the SIBE of Bouhachem.

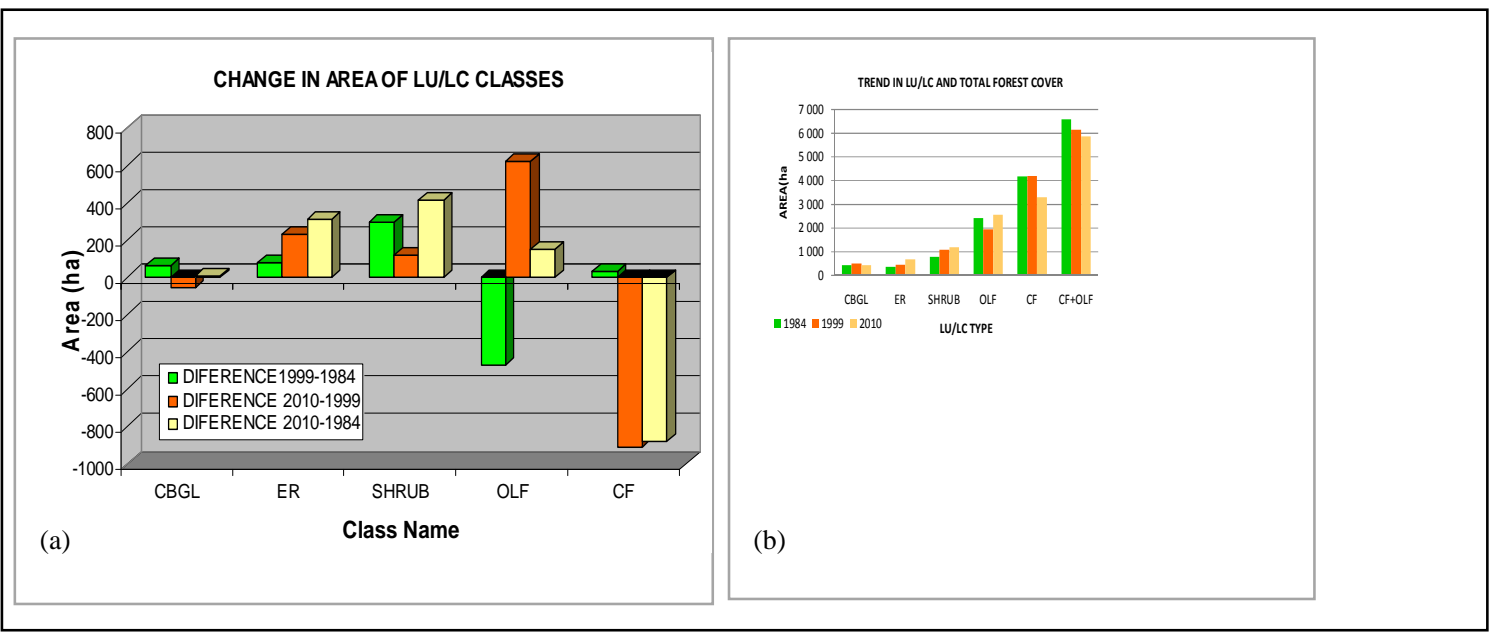

Figure 4 : Progressive decrease in total forest area change in LU/LC areas between1984-19992010. 


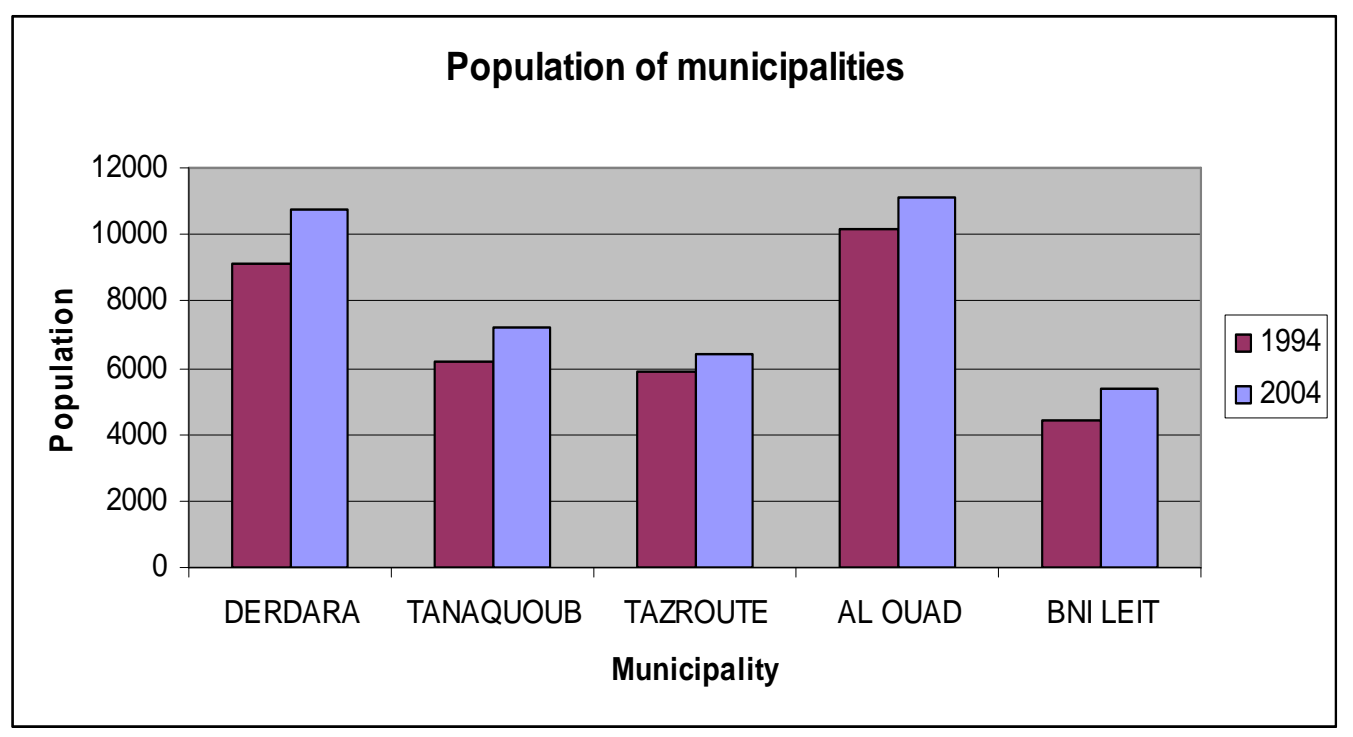

Figure 5: Population growth in the communes of the SIBE.

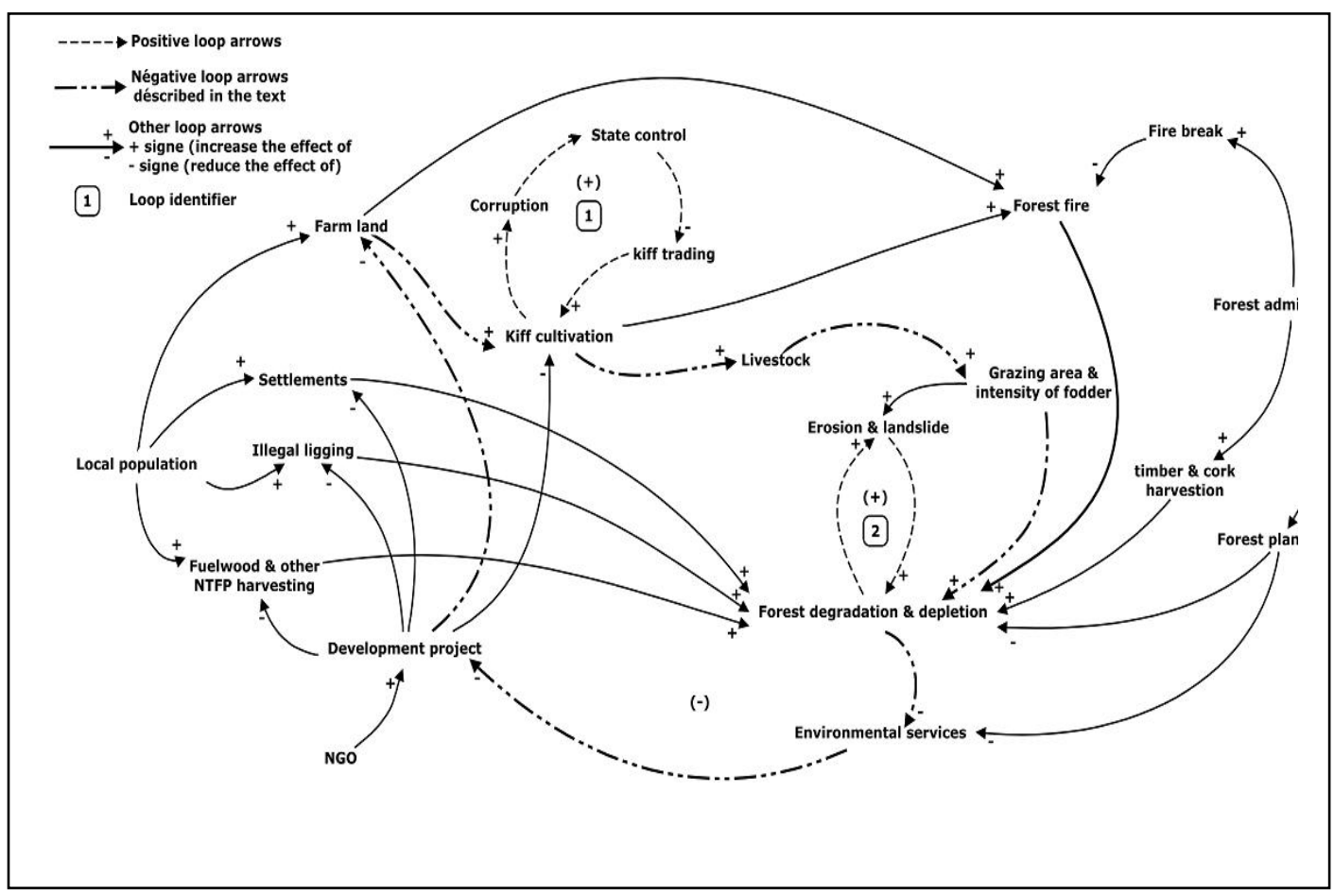

Figure 6: Model of deforestation in Bouhachem area. 


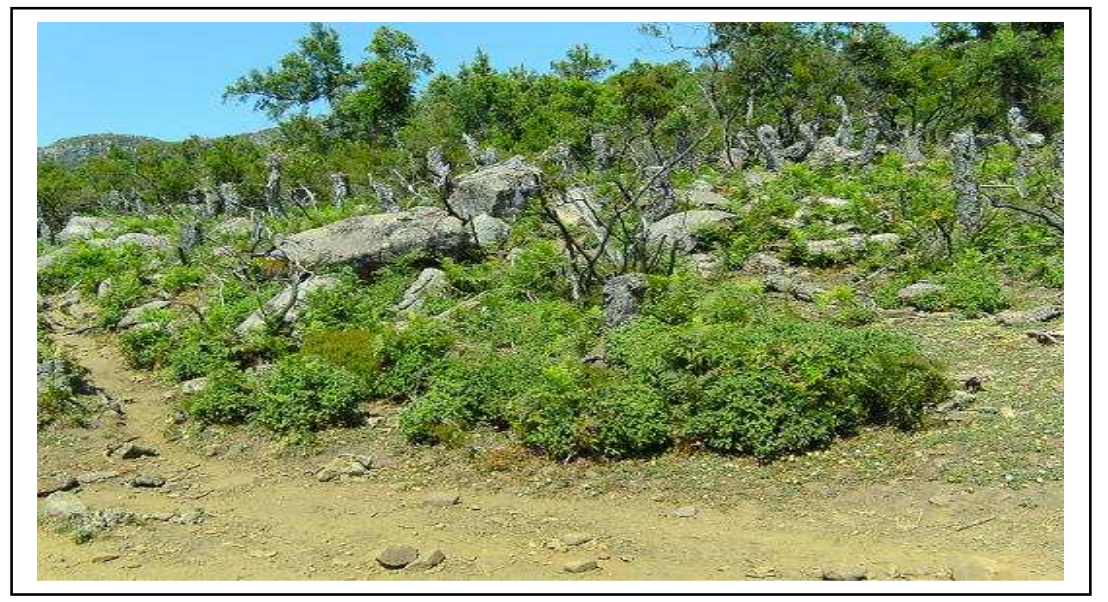

Figure 7: Tree stumps along livestock track.

Table 1: LU /LC change dynamics of the study area.

\begin{tabular}{|c|c|c|c|c|c|c|c|c|c|}
\hline \multirow[b]{2}{*}{$\begin{array}{l}\text { Class } \\
\text { name }\end{array}$} & \multicolumn{9}{|c|}{ Evolution of the surface area per LU/LC (ha) } \\
\hline & \multicolumn{2}{|c|}{1984} & \multicolumn{2}{|c|}{1999} & \multicolumn{2}{|c|}{2010} & $\begin{array}{l}\text { Difference } \\
1999-1984\end{array}$ & $\begin{array}{l}\text { Difference } \\
2010-1999\end{array}$ & $\begin{array}{l}\text { Difference } \\
2010-1984\end{array}$ \\
\hline$\overline{\mathrm{CBGL}}$ & 429 & $5.3 \%$ & 494 & $6.0 \%$ & 437 & $5.3 \%$ & +65 & -57 & +8 \\
\hline ER & 375 & $4.6 \%$ & 453 & $5.5 \%$ & 682 & $8.3 \%$ & +78 & +230 & +307 \\
\hline SHRUB & 781 & $9.6 \%$ & 1077 & $13.2 \%$ & 1194 & $14.6 \%$ & +296 & +117 & +413 \\
\hline OLF & 2414 & $29.5 \%$ & 1944 & $23.8 \%$ & 2562 & $31.3 \%$ & -470 & +619 & +148 \\
\hline $\mathrm{CF}$ & 4176 & $51.1 \%$ & 4207 & $51.5 \%$ & 3299 & $40.4 \%$ & +31 & -908 & -877 \\
\hline TOTAL & 8175 & $100 \%$ & 8175 & $100 \%$ & 8175 & $100 \%$ & & & \\
\hline $\mathrm{CF}+\mathrm{OLF}$ & 6590 & & 6151 & & 5861 & & -439 & -289 & -729 \\
\hline
\end{tabular}

Difference X-Y: difference in the size area of the correspondent LU/LC class of year X and year Y. Minus (-) in front of a class change means the lost of area in the concerned class, and the plus means a gain of area in the class concerned. CF+OLF: sum of area of Closed Forest and Open/Light Forest.

Table 2: Presence or absence of stumps in Bouhachem forest.

\begin{tabular}{lcc}
\hline Presence or absence of stumps & Number of plots & percentage \\
\hline Presence & 308 & $61.47 \%$ \\
Absence & 193 & $38.53 \%$ \\
Total & 501 & $100 \%$ \\
\hline
\end{tabular}

\section{DISCUSSION}

Causes of land cover change in the SIBE of Bouhachem

Settlement and population growth and encroachment

The presence of build up areas in the image of 2010 can be attributed to the increase of population experienced by this area during the last decades (

Figure 5). In fact, the population settled around the reserve passed from 35857 inhabitants in 1994 to 40918 in 2004. This rise in population $(14.1 \%)$ has had as consequence an increase in various demands: fuel wood, 
construction material, settlement area, agricultural land mostly for cannabis cultivation, etc. As far as settlements area is concerned, infractions of construction were recorded in the area, proving the significant pressure that is being exerted on the forest area leading to shrinkage.

\section{The SIBE of Bouhachem and its Perception by the villagers}

Depending on whether you are in the northward looking or in the southward looking part of this protected area, its perception is different. In the northern part of the forest, notably in douars like Ramla, Tayensa, Moulay Abdesslam, and Tazrout, a project on the development of ecotourism has improved ecotourism activities, and has led to develop another perception of the forest and to understand the importance of preserving the nature. Therefore, the forest is less destroyed in this part, even though tourism could have side effects on the nature and the local communities. In this same way, Cables et al. (2007) supported that the promotion of ecotourism can provide the management of sustainable levels of forest product, and grazing on forest lands. However, the populations of the southern part of the forest are not yet getting benefits from tourism activities as such. In this part of the forest, people care less when they are carrying activities in the forest. Livestock being their main domain of investment of money gained from cannabis crops, the forest is mostly considered as pasture land or reserve of land for cannabis cultivation, leading to a high pressure on this forest part.

\section{Insufficient surveillance and corruption}

The existence of corruption between farmers and rangers is well known in the area. Many rangers are incarcerated because of their implication in bribery related to kiff cultivation. These issues of corruption are well known in the upper sphere of the administration and some trials are launched against forest rangers. Corruption in forestry was considered by the United Nations Office on Drugs and Crime, (2012) as a tool for environmental crime. Other problems which render the control of the area difficult are its situation in the confluent of three provinces. Taking into account the fact that a forest ranger should not patrol alone, (but paradoxically, only one ranger is assigned per forest sector), and the administration bottleneck, the coordination of the control of the forest between forest workers is therefore difficult.

\section{Erosion and landslide}

Erosion activities and landslide phenomena are also causes of LU/LC change in the forest. Among the 501 plots inventoried, erosion activities were observed on $55.1 \%$ of the plots. This phenomenon was emphasised in area with high concentration of cannabis farms, leading to increase rock exposition. In fact, Barringer (2013) and O'Hare (2013) also acknowledged that cannabis cultivation or agriculture are direct source of soil erosion.

\section{Patterns and impact of encroachment related to cannabis \\ Cannabis cultivation as the driving force of deforestation}

The slash and burn method makes encroachment in the forest easier following two different ways: clear cut followed by burning for immediate cultivation the same year, or, clear cut the forest and cultivation one or two years later. These two methods of establishing new farm land are reflected in the minutes of the office of litigation and material of the forest administration. According to Figure 7, the number of "slash and plough" infractions was greater than those of "slash" or "plough" showing an urgent need of new land between early and end 1990 . This period of general increase in the number of infractions corresponds to the period of intensification of cannabis cultivation in the area. This number of infractions drastically reduced at early 2000, when the campaign against cannabis cultivation was intensified under the control of the United Nations Office on Drugs and Crime (2003). Nowadays, cannabis cultivation is increasing again.

Income from cannabis is mostly used to acquire cattle. The aftermath being an increase of the Stocking rate, passing from an 
extreme level of 2.2 LSU/ha/y (Tribak, 2000), to a critical one 2.6 LSU/ha/y (Suber, 2010). Among the 501 plots inventoried, 87\% presented signs of grazing, showing the high pressure made by grazing on the forest. Generally, the practice consists of moving in the forest and cutting tree branches as fodder for livestock during winter. In the summer time, animals are taken in the forest for grazing and when the grasses are all dried, shepherds very often cut branches or the entire tree for livestock to feed on. The impact of cutting trees for fodder on the forest is illustrated in Table 2 where more than $61 \%$ of inventoried plots presented stumps and their density could rise up to 2149 stumps/ha, often with diameter less than $7.5 \mathrm{~cm}$. These stumps are mostly observed either in areas nearby the villages, beside cultivated area, around the small meadow where animals often spend the night or along the main tracks used by the livestock to move in or out of the forest (Figure 8). These practices lead to a progressive transformation of closed canopy forest into open forest or shrub land.

Cannabis cultivation is the main reason of searching for new fertile soils, and therefore for clear cutting the forest. This was also observed by (Taiqui, 2003) and (Taiqui et al., 2008) in the province of Bouhachem. The reduction of the number of minutes observed at early 2000 synchronises with the period of reduction of the cannabis cultivated surface area following a campaign again drugs, conducted in the country by the Office of United Nations Office against Drugs and Crime (United Nations Office on Drugs and Crime., 2003). The Bouhachem forest is burnt almost every year. Between 2000 and 2009, in average, 28 ha of forest were burnt every year, while 1.2 ha per year was burnt between 1990 and 1999 in this area. This is related to the change of behaviour of farmers to escape the fines. In fact, the surrounding populations are making more and more use of bushfire to obtain new land for cannabis cultivation, trying to escape the fines applied for forest clear off, and paying only the fine of plough for sowing cannabis.

\section{Causal loop diagram model of deforestation in Bouhachem and its feedback loops}

The causal loop diagram of deforestation in Bouhachem forest (Figure 6) presents three main stakeholders gravitating around forest resources. Firstly, the Forest Administration, representing the State, acts mostly in road opening, fire break establishment, forest plantation, timber and cork harvesting. It is also responsible for forest control, and its workers are likely to be corrupted by local communities. Secondly, local population are the most users of forest resources: they harvest fuel wood and other Non-Timber Forest Product (NTFP); they are often responsible of illegal logging, and they are implicated in clear cutting forest patches for establishing new settlements or opening new farm land. In this farm, they crop cannabis and are often involved in bribery. Money gained from cannabis cultivation is invested to acquire livestock. This livestock is taken into the forest for grazing and trees are wildly pruned or failed for leaves to be used as fodder. Thirdly, Non-Governmental Organisations (NGOs) are involved in implementing development projects. These projects may tackle the problem of deforestation due either to fuelwood and other NTFP harvesting, settlement, illegal logging, farm practices, cannabis cultivation, or even livestock grazing practices. These entanglements of causes and effects develop two positive feedback loops (hidden lines) and several negative feedback loops where development projects play as a veritable central nervous.

The positive feedback loops (1) shows that: the higher the quantity of cannabis cultivated, the higher the trend to corruption, the high trend of corruption lead to reducing the quality of control by administrative workers. The poor quality of controls will lead to favour cannabis trading, and the easier cannabis is traded, the more local communities will involve themselves in its cultivation. The positive feedback loop (2) reveals that forest degradation and depletion favour erosion and landslide in the area, and 
erosion and landslide lead to deforestation. The negative feedback loops are focused around development projects which aim to mitigate the harmful uses of forest resources. For instance (phantom lines), the increase of population will lead to the need of opening new farm lands. The higher the area of farm land, the higher the quantity of cannabis produced. Money earned from cannabis allows the farmers to acquire more livestock. The higher the quantity of livestock, the bigger will be the area needed for grazing or more intensive will be the pruning of trees for fodder. The search for more area for grazing and fodder will affect forest quality and area. Forest degradation and depletion will lead to the reduction of environmental services and quality. The degradation of environmental services will draw the attention of NGOs who can react by designing more development project to tackle the problem of opening more farm lands.

considered by Dueser and Shugart (1978) as a variable for measuring forest habitat structure, stump density has been estimated in many studies in the past. Some of them were interested in estimating the attributes of forest fragmentation or degradation (Gillespie and Chapman, 2005), or to study the structural and diversity aspect of a forest (Linares et al., 2011). According to Thapa and Bhuju (2011), cut stumps substantiate the evidence of human pressure on forests. As stated by Gillespie and Chapman (2006), an easily measurable index such as the number of stumps which is a pattern likely to be common in disturbed areas can be used to predict the degree to which a fundamental ecological process can be altered by human disturbance, and this may represent an unrecognized threat for the conservation and management of various habitats. Stump Rate can therefore be seen as an interesting indicator to appreciate the degradation of forest environment due to grazing activities. In the northern part of Morocco, the stump density was estimated at 187 /ha, which is greater than 39.56/ha and the 107.7 found respectively by Paudyal (2007) and Thapa and Bhuju (2011) and qualified to be highly cut.
But, these last authors did not calculate the Stump rate in their study which could allow having a better idea on human pressure in their area of study. Further studies estimating the stump rate have to be carried out in the area in order to have comparative data.

One of the challenges to take Bouhachem forest out of the actual vicious cycle of deforestation can be to develop and implement policy and practical approaches for achieving ecologically sustainable forest management by integrating economic, social, cultural and environmental values into participatory forest management. The mountain structure of Bouhachem predisposes this area to mountain tourism which can be a good alternative for seaside tourism. In fact, this project has started to show some results in the northern side of the forest, and need to be extended in the southern part too. In this same wise, by multiplying alternative income generation activities which are less aggressive to the forest could lead to reducing its depletion. The example of bee keeping can be a good project, but need to be well implemented and some rules like forbidding honey harvesting during summer could give a good result.

\section{Conclusion}

This work shows that Bouhachem forest still has its natural characteristics, but this is seriously affected. Serious changes in the reserve during the 26 years of assessment have been observed. It shows a great reduction of closed canopy forest in favour of open canopy forest matorral, cultivated grass and bare lands as well as exposed rock. However, forest cover in the area has shrunk. The reasons behind forest area depletion are mostly the pressure exerted to acquire new farm lands by the increasing population. In these farms are cultivated cannabis from which income is invested to acquire more livestock. The quantity of livestock grazing in the forest is extremely high, leading to over grazing, over pruning and trees falling.

Further significant driving factors are erosion and landslide, the perception of the forest by the surrounding population and 
forest fire. The interconnection between these factors leads to trap Bouhachem forest in a sort of vicious cycle of deforestation. The analysis of stakeholder using the causal loop diagram shows that a solution to mitigate deforestation can be the implementation of development projects.

\section{ACKNOWLEDGEMENTS}

The authors are grateful to the Forest Sciences Centre of Catalonia (CTFC) and the SUTROFOR for their financial support. They also extend their gratitude to Odile Nkoua Ablan and Magda Pla for their technical assistance during data analysis. They give a special thanks to Dr. Sylvie Durieu for her comments to improving this study.

\section{REFERENCES}

Barringer F. 2013. Marijuana Crops in California Threaten Forests and Wildlife. New York Times: New York.

Cables R, Peterson M, Chaveas M, Othman M. 2007. Technical Assistance Scoping Mission to the US Agency forInternational Development and the Moroccan Haut Commissariat aux Eaux et Forets et à la Lutte Contre la Désertification: Mission Dates: May 5 19, 2007, US Forest Service International Programs, Department of Agriculture, Kingdom of Morocco.

Chambouleyron M. 2012. Contribution à la Connaissance de la Flore de la Péninsule Tingitane (MAROC), Lagacalia, 32: 35227.

Chokona GH. 2006. Evaluation of logging impacts in tropical rainforest using remote sensing and GIS techniques. memoire PGD. Ile-Ife, Nigeria: ARCSSTEE, OAU, Ile-Ife,Nigeria, 70p.

Chokona GH. 2011. Landscape dynamic assessment in the Site of Bio-Ecological Interest of Bouhachem, Morocco. SUTROFOR European Master of Science in: Environmental management and policies for tropical forests. Montpellier: AgroParisTech-ENGREF Centre de Montpellier.
CTFC. 2010. Gestion Durable du Capital Naturel de la Foret de Bouhachem (Chefchaouen, Maroc): Garantie des Benefices Sociaux, Economiques et Environnementaux: Rapport de Mission de Classement de Peuplements, Bouhachem, Maroc: CTFC.

Dueser RD, Shugart HH. 1978. Microhabitats in a Forest-Floor Small Mammal Fauna. Ecology, 59(1): 89-98.

FAO. 2010. Global Forest Resources Assessment 2010, main report, FAO Forestry Paper 163, Rome. Available at: www.fao.org/docrep/013/i1757e/i1757e.p df.

Gillespie TR, Chapman CA. 2006. Monkeydung Study Offers Clues About Land-use, Wildlife Ecology. Science Daily. Available at: http://www.sciencedaily .com/releases/2006/04/060408124454.ht $\mathrm{m}$ [Accessed September 26, 2012].

Haut-Commissariat au Plan. 2005. Recensement Général de la Population et de l'Habitat de 2004. Population Légale du Maroc.

International Birds of the Strait Fair. 2010. Intercontinental Biosphere Reserve of the Mediterranean. Available at: http://www.feriadelasavesdelestrecho.co m/reserva_ing.html [Accessed November 08, 2013].

Kamel S. 2009. Le cannabis: mine d'or pour les uns, mirage pour les autres. Available at:http://fmpdci.sistematizacion.org/entret iens/liste-des entretiens/?tx_panel_pi1\%5 Bafficher\%5D=det_entretien\&tx_panel_p i1\%5Buid\%5D=42 [Accessed November 08, 2013].

Leguet J-B. 2008. Analyse des impacts anthropiques sur les dynamiques forestières d'une vallée du Haut Atlas. Mémoire de fin d'études d'Ingénieur de l'ENITA. Bordeaux: Ecole Nationale d'Ingénieurs des Travaux Agricoles de Bordeaux, 53.

Linares JC, Carreira JA, Ochoa V. 2011. Human impacts drive forest structure and diversity. Insights from Mediterranean mountain forest dominated by Abies 
pinsapo (Boiss.) European Journal of Forest Research, 130(4): 533-542.

Ngufor V. 2010. Detecting Forest Cover Change Induced by Encroachment Using Remote Sensing and GIS; a Case Study of the Bafut Ngemba Forest Reserve. North -West Province of Cameroon. Master of Science thesis. Dresden, Germany, p. 75.

O'Hare M, Alstone P, Sanchez DL. 2013. Environmental Risks and Opportunities in Cannabis Cultivation, BOTEC analysis corporation I-502 Project, $32 \mathrm{P}$.

Paudyal A. 2007. Buffer Zone Resources and Community Conservation: A case study of Piple BZ VDC, Chitwan National Park. MSc. Kathmandu, Nepal: Central Department of Environmental Science, Tribhuvan University, p. 73.

Regato P, Salman R. 2008. Mediterranean Mountains in a Changing World: Guidelinesfor developing action plans, Malaga, Spain: IUCN Centre for Mediterranean Cooperation.

Service des Eaux et Forêts du Maroc. 2004. Carte d'orientation du projet de parc régional de Bouhachem.

Suber M. 2010. Degradation drivers over Quercus woodland in Bouhachem Mountain, northern Morocco. Master of Science thesis in Environmental management and policies for tropical forests. Montpellier: AgroParisTechENGREF Montpellier Center, p. 32.

Taiqui L. 2003. Evolution Récente de la Structure du Paysage du Bassin de Chefchaouen (1958_1986). Mutation des
Milieux Ruraux dans les Montagnes Rifaines (Maroc); 179-206.

Taiqui L. Martin J, Seva E. 2008. Structure, diversité et dynamique des suberaies du paysage rural de Chefchaouen. annales de la recherche forestière au Maroc, 39: 4357.

Thapa A, Bhuju DR. 2011. Buffer Zone Resources and CommunityConservation: A Case Study of Handi Khola Buffer Zone User Committee,Parsa Wildlife Reserve. Nepal Journal of Science and Technology, 12: 230-237.

Tribak A. 2000. L'érosion hydrique en moyenne montagne du Prérif oriental (Maroc). Etudes des agents et des processus d'erosion dans une zone de marnes tertiaires. Ph.D. Thesis. El Jadida: Univ. Chouaïb Doukkali, p. 350.

United Nations Office on Drugs and Crime 2003. Morocco Cannabis syrvey 2003 Executive Summary, $13 \mathrm{p}$ available at : ttp://www.unodc.org/pdf/publications/mo rocco_cannabis_survey_2003_exec_sum. pdf [Accessed November 15, 2013].

United Nations Office on Drugs and Crime. 2012. Corruption, Environment and the United Nations Convention Against Corruption, Indonesia.

Weber F, Beaud S. 2003. Guide de l'enquête de terrain. Produire et analyser des données ethnographiques, Paris: La Découverte. 